QIJIS: Qudus International Journal of Islamic Studies

Volume 7, Number 2, 2019

DOI : $10.21043 /$ qijis.v7i2.4847

\title{
CAPITULATION AND SIYASAH SYAR'IYAH AL-MALIYAH IMPACT ON ECONOMIC STABILITY OF THE 18TH \& 19TH OTTOMAN TURKS
}

\author{
Desmadi Saharuddin \\ Universitas Islam Negeri Syarif Hidayatullah Jakarta \\ desmadi.saharuddin@uinjkt.ac.id \\ Meirison \\ Universitas Islam Negeri Imam Bonjol Padang \\ meirison@uinib.ac.id \\ Inayatul Chusna \\ Universitas Islam Negeri Syarif Hidayatullah Jakarta \\ inayatul.chusna@uinjkt.ac.id \\ Ade Sofyan Mulazid \\ Universitas Islam Negeri Syarif Hidayatullah Jakarta \\ adesofyanmulazid@uinjkt.ac.id
}

\begin{abstract}
Free trade and foreign investment that characterize the $21^{\text {st }}$ Century trade and business model do not benefit all parties, particularly Islamic countries. Only those who have well-established economic system and large capital gain the most benefit. This condition had occurred during the Ottoman Khalifah. Therefore, this article aims to prove that free trade and foreign investment during the Ottoman, in the form of capitulation, brought negative impact on the Ottoman's economy and politics. Capitulation is an agreement between the Ottoman and Western European countries that regulated economic and legal sectors by giving privilege to the European countries to come and trade in the Ottoman. The Ottoman
\end{abstract}


became a free market place that eliminated the Islamic economic system. The Ottoman saw the agreement as its Siyasah Syar'iyah Al-Maliyah to protect the political sovereignty when facing European countries. Once the agreement benefited the Ottoman, later it caused economic political problems. The domestic industries faced difficulty when competing with foreign trades. The Ottoman government did not have full authority over the law and justice of the Europeans in the Ottoman. The capitulation that was expected by the Ottoman to protect its economy and politics had put the country under the domination of Western Europe. What happened to the Ottoman is proof that the free market is only beneficial to developed countries with active industries. Therefore, this historical fact should be reference for Islamic countries in conducting their foreign economic system.

Keywords: Capitulation, Ottoman Turks, free-trade, eestern countries.

\section{A. Introduction}

Foreign capitulation is the most crucial element in the catalyst for the development of the Ottoman Turkish economy, especially during the peak of Sultan Muhammad al-Fatih's regime (1451-1481), as well as to control political balance on the European Continent. Political accidents occurred during the time of Sulaiman al-Qanuni (1520-1566) when the Sultan had a multidimensional vision of Western European countries, but the Western European countries saw Ottoman Turks as a unified front, a part of Islam. It led to Capitulation policies that are not beneficial in politics, power, and force. The result of such policy changed when the economic and military force shifted. Foreign Capitulation has become a double-edged sword through excessive use (Syaqiraat, 2016, p. 15). 
Capitulation is an essential facilitation and ease in trade transactions and property protection provided to individuals who are considered as foreign nationals. A treaty that applies to the countries that signed the agreement as well as in the Ottoman Turks' territory was made in full force. The Capitulation Agreement was executed with Venice and France during the triumph of the Ottoman Turks. This did not have a significant negative impact on Ottoman Turks and even resulted in profits when it broke the concentration of Western European countries united against the Ottoman Turks (alIzari, 2003, p. 23).

Over time, the agreements made with Venice and France turned to a catastrophe due to changes in political, economic, and military isolation. In the 18th and 19th centuries, about two hundred years later, the Ottoman Turks underwent degradation in all aspects of their government so that the agreement with the foreign powers turned into fetters and spread chaos and agitation throughout the Empire. The foreign states pressured Turks to comply with all previous contractual agreements because it would benefit them and harm the Ottoman Turks. In practice, the foreigners assumed and misused all the arrangements to their benefits, and the Ottoman Empire is powerless against the pressure exerted by the European countries (Meirison, 2019).

In Islamic economic principles, the practice of monopolizing the needs of many people is prohibited. But, this is done by the Ottoman rulers by granting capitulation rights to foreign countries (France, Britain and the Netherlands). The right of capitulation given to foreign countries was very detrimental to the people of Turks because the contents of the 
agreement led to trade monopolies, weakening of production factors, and controlling prices of goods for the needs of the people in the country. This political decision had a negative impact on the Turkish industry because the contents of the capitulation agreement provided tax relief for imported goods made by foreign countries that had the capitulation right. This policy was carried out by Turkish rulers, including Sulaiman al-Qanuni, to defuse the pressures of his political opponents, especially from countries fighting with the Ottoman Turks such as the Hapsburg family who came from Spain.

Implicitly, this capitulation agreement is a siyasyah shar'iyah which is an alternative to reject loss (war). Then, siyasyah is also in line with the Maqasid Syar'iyah which aimed at achieving greater prosperity by avoiding wars and pressures of political opponents that would disrupt the economic stability and the Ottoman Turkish government. If this siyasyah was successful in anticipating greater disadvantage, the Turkish people could do better economic production activities without interference from foreign politics. However, it was unfortunate that the tax imposed on domestic production was so burdensome so that they were unable to compete with imported goods. The protection of domestic production was an absolute necessity for the defense of a country's economic system. This had been widely reviewed by economic thinkers such as Ibn Khaldun (Fitriani, 2019).

"Ibn Khaldun asserted that the country's wealth is not determined by a large amount of money available and circulating in the country but is determined by the country's production level and a positive balance of payments. A country 
can print money as much as possible, but if it is not a reflection of the rapid growth of the production sector, sufficient cash is no value. The production sector which is the driving force of development absorbs labor, increases the income of workers, and raises the demand for other factors of production. This opinion also shows that international trade became the main topic of the scholars at that time. Countries that export a lot means to have a production capacity more significant than their domestic needs shows that the country is more efficient in its production".

The Contractual Agreement (Foreign Capitulation) became a gateway for the western countries to take over various aspects of life in the Ottoman Empire. Pressure and intervention by West Europe were felt as the Ottoman Empire grew weaker economically. One of the manifestations of such Agreement was the release of Foreign nationals involved in a contract from their tax obligations or reduction in the number of tax payables. This clause incurred losses to the Ottoman Turks. It was worse when the rights were traded between foreign nationals who were involved in the contractual agreements and those who were not included in the transaction. Other various forms of Foreign Investment resulted directly in economic losses on the part of the Ottoman Turks.

The Ottoman Turks could not solve many issues as a result of this Agreement, such as civil and criminal violations by foreign nationals which were resolved at the consulate. Similarly, the domestic economy could not be controlled because foreign traders and non-muslim minorities were under the legal protection of West Europe; therefore, all 
forms of violations on their part were to be resolved at foreign consulates in Istanbul. This condition resulted in power within power, which affected the political and economic situation in Ottoman Turks.

The Ottoman Turks had been excessive in executing agreements (foreign capitulation) with European countries of the 17th century. Countries involved in the agreement with the Ottoman Turks included Sweden, Denmark, Prussia, Spain, United States, Beljicka, Germany, Portugal, Greece, and Brazil. They signed capitulation agreements primarily in commerce and religious fields. There were also old players such as the British, Dutch, Italians and French. Meanwhile, Switzerland and the Papacy (Vatican City) were also in both agreements under the protection of France (Syaqiraat, 2016, p. 15).

\section{B. Political Contracts and Realization of Foreign Capitulation in Turks}

Ottoman Turks's foreign policy was rooted in its political life and long historical journey. It was such a political journey that established fellowship and covenant with other countries over the times. When Charles Quint turned hostile against the Ottoman Turks, Martin Luther came and broke Catholic unity in Europe, spread his ideas in schools throughout Europe, and resulted in European countries being fragmented into the existing schools. Martin Luther waged a religious war against the Catholics and Papal government in Europe. Such conditions indirectly had positive impacts on Ottoman Turks's military campaign in Central Europe. The Sultan took an opportunity from the ideological war between the Catholics and Protestants in Europe. He established an exceptional communication with the Protestants for seeking 
common grounds between the new religion and Islam (alIzari, 2003, p. 22). On the other hand, the Ottoman Turks entered into an official agreement with France to justify its attack against Charles Quint, who took control of Austria and Spain.

In $1583 \mathrm{AD}$, there was a renewal of agreements with other countries when the UK entered the fray. Turks made various preparations and counted every possibility of gaining leverage against Austria. However, the Sultan's wishes which existed in the agreement made with European countries turned out different from the reality amidst war. Although European countries had conflicting interests, they shared a common view because of their religious beliefs - they were deeply concerned about the development of Islam and its continued expansion of territory by the Ottoman Turks.

When instructed by the Pope, all the European countries mobilized against the forces of Islam -preceding the longbrewing dispute between them to defeat the Muslims and their politics which were always considered a threat. Some experts and histories expressed the reason behind French, British and Dutch interests and involvement in Contractual Agreement with Turks - it was to support the Ottoman Turks against its enemies, the Papacy of Rome and the Hapsburg dynasty. It was very reasonable, but the reality couldn't be further from the truth. The King of France reminded the Pope in Rome and the King of Britain to take benefits from the Foreign Capitulation agreement. Meanwhile, the Ottoman Turks enemies, the Papacy of Rome and the Hapsburg dynasty. It was at the same time, the French included the Pope in the Foreign Capitulation Agreement (Azawi, 2003, p. 23). 
Another fact which should not be discounted was the influence of the Pope in Rome on European countries at that time. The Pope was able to control alliance borders between the Ottoman Turks and Charles V and Francois I, uniting Europe against Islam (Veblen, 2005, p. 37). Sultan Sulaiman's wish did not match reality. The countries involved in the Capitulation Agreement reneged on the agreement after they successfully achieved the objectives and benefited from it. The execution of the agreement between France and Ottoman Turks was a great taboo for the European Christians.

Historians believe that the Ottoman Turks had obtained the benefits of such agreement as proven by the close ties between the Empire and France. The French were expected to bail out of the crusade coalition comprising of European countries against the Ottoman Turks, especially regarding the maritime war for the Mediterranean Sea led by Charles Quint. The author thinks that it was not entirely true because at that time France was surrounded by Charles Quintil out more giant sea armada. To arm 20 warships alone, France had difficulties in untrained military personnel compared to those of Ottoman Turks or the Habsburg Dynasty.

In $1526 \mathrm{AD}$, France successfully escaped the siege by the Habsburg dynasty in two of its conquered areas: Magzayorzag and Hungary. Meanwhile, the cities of Buda and Pest (Budapest) became the two newest cities in Ottoman Turks at that time. In 1537 AD Ottoman Turks deployed naval aid to France in their attempt to invade Italy from the south, when at the same time, the French army would attack from the north. The aid from Ottoman Turks came for the second time in 1543 AD when Sulaiman instructed Khairuddin Aruj 
Barbarossa to sweep the Italian territory and proceed to invade France from the south. Ottoman Turks gave all military aids to France in return for nothing at the request of King Francois I. At that time, France was assisted by Ottoman Turks to prevent the expansion of the Hapsburg dynasty across all of France. Turks also provided trade privileges to France which had not been given to any other country. This analysis was justified by the fact that Ottoman Turks was a stable country with the incomparable strength forces at that time. However, another question arose as to why the Sultan included Britain and the Roman Pope in an agreement that outright supported Charles V. Whether the Sultan aimed to assist its enemies in preventing the expansion of Islamic culture and ideas in Europe. (Azawi, 2003, p. 22).

Raider Pollard, a British diplomat, stated that foreign capitulations made by Ottoman Turks were easy to control when European countries were in a weakened state. The Capitulation only benefited Turks when it was loud in which it served as a means to attract sympathy and break the European countries when European countries were in a weakened state. Then Turks began to weaken, the agreements became the threat and double-edged sword. Under a signed contract agreement, Europe rejected Turks's demand for tax increases that would be used to pay its debts and interest. The method of payment of the debt was governed by a foreign institution with only one member from the Ottoman Turks (Salman, 2015). The treaty has been formally agreed to protect Venetians in Istanbul and other regions. Forms of protection included the right to own slaves and impose a will between them (about ownership) with the imposition of a $2 \%$ import tax (except 
for printed silver or silver ore which they had to prepare for the Sultan for currency printing). There were several irregular clauses which became an extraordinary political competition between the Sultan and Geneva (Genoese). For example, Pizza was required to pay debts to the deserving party that was the Venetian community in the Ottoman Empire. They were allowed to enter the Ottoman port with protection on themselves and their possessions; at the same time, Ottoman Turks traders also hoped to get similar treatment from Venice (Mantran \& Bacqué-Grammont, 2003, p. 125). Later in the agreement also explained about the appointment of the Venetian ambassador who settled in Galata (an area within the city of Istanbul) with special privileges in which he was given the freedom to handle political affairs, commerce, and law (Brockelmann et al., 1982, p. 440).

When Constantinople was conquered, regardless of whether Venetia liked it, it must obey the rules imposed by the Ottoman Turks. Venetia was involved in commerce across the Mediterranean and the Black Sea. Ptolemy Marcelo, an emissary of the Duke of Venice, appeared before Sultan Muhammad al-Fatih renewed the Adana accords and include additional terms to the agreement. Venice was the first European country to send an emissary to Istanbul which marked the start of the Foreign Capitulation system in Ottoman.

The agreement contained the following terms (Qari, 2001, pp. 220-225): 1. No more protection will be given to a criminal of another nationality, and thieves must be turned over immediately to the state along with the stolen objects. 2 . The merchants of both countries shall be free to enter both 
countries' territory by land or sea without any impediment. 3. The Duke of Nassau and his people, are included in this agreement and shall be exempted from tax and any such payment and shall be free to conduct any activity whatsoever. 4. All ships of both parties will be welcomed and not be subject to any hostile action. 5. Venice will pay a total of 436 Ducat as customs fee at Lepanto port and the cities of Soctari, Lisboa, and Drifasto in Albany. This payment will be made to the Governor of Istanbul.6. All Venetian slaves shall be freed without charge, except if they converted into Mohammad's religion, in which case they must pay one thousand Piaster for their freedom. 7. Disregarding the absolute freedom of Venetian merchants in the Ottoman Turks's territory, they are required to pay $2 \%$ of the total value of goods they carry with them. A similar rule also applies to Ottoman merchants conducting activities in Venice. 8. All ships coming and going on the Black Sea and sailing to open seas must obtain permission from Istanbul and carry the necessary logistics for sailing on open seas. 9. Merchandise from Christian countries that originated from the Black Sea and the Mediterranean Sea for sales through the Venetian merchants, who are not allowed to carry Muslim goods. 10. Venice imposed taxes except for confiscated goods or those related to the people of Geneva. 11. The people of Venice, are allowed to pay the Patriac pilgrimage in Istanbul. 12. Each country shall give protection to personnel and merchandise on board of damaged ships on their water. 13. If a Venetian citizen dies without leaving a will or an heir, his inheritance must not be used and shall be handed over to the consulate, magistrate, or administrator for delivery to the consulate general or another 
Venetian merchant until it is requested by the Duke of Venice. 14. Do not assist an enemy of the countries involved in the agreement. 15. Neither party is allowed to protect an enemy of both countries taking refuge inside castles, forts or cities owned by the Duke in Rome and Albany. No financial support shall be given to the enemy, and the Sultan has the right to declare war in the name of the territory of city or country or fort which granted him protection. However, a war against a territory or a fort does not necessarily cancel or revoke an agreement. Such obligations also apply to the Ottoman State against the Duke of Venice. 16. Venetians can assign a consul to Istanbul according to needs and in compliance with the applicable statutory. They have the authority to decide on administrative proceedings and other disputes. The Sultan shall instruct an Administrator or Military District Leader of Romeli to assist the consul in settling a dispute. 17. The Sultan (Daulah Usmaniah) promised to repair and replace any damage or injury to a person or asset caused by Ottoman Turks's conquest of Istanbul under the principle of fairness. 18. Venice is entitled to bring over their assets and currency into the Ottoman country, in printed or raw forms, without paying any tax provided that the metal ore must be presented to the money printing office. 19. The debt of the people of Istanbul, shall be written off, especially Venetians, after the conquest of Constantinople. Such obligations shall be deemed void by the law. At a glance, the capitulation provided by Muhammad al-Fatih to the Kingdom of Venice is similar to that given by Sulaiman al-Qanuni to the Kingdom of France. However, the Foreign capitulation by Muhammad al-Faith is worthier of study since it occurred during a great victory, which was a 
transitional point from the dark ages to the modern era. The conquest of Constantinople opened the European market to products from the East.

A similar agreement was also carried out with Moldavia in 1465. Geneva, which was included in the agreement, also enjoyed a tax reduction facility and the freedom to conduct trade across the entire territory of the Ottoman Empire. Since Geneva helped the Ottoman Turks in the war against the Orthodox Christians who were opposed to the Catholics settling in the Ottoman Turks's territory (Kotrani, 1986, p. 410). As such, the Ottoman Turks had contributed to the dynamics in the European trade activities since Venice was a country with the most significant trade volume at that time in Europe. Meanwhile, another major trader in Europe was Geneva(Farid Bek Al-Muhami, 2009, p. 157). Russia was not about to be left behind - it proposed to reap the benefits of the capitulation through the Crimean rulers.

Similarly, Geneva was also given the privilege of occupying small islands such as Taxos and Imbrus. In 1464, the kingdom of Florence in Italy was given the opportunity and facility in commerce to balance out and suppress the trading power of Venice which often tried to overtake Ottoman Turks. Muhammad al-Fatih also succeeded in containing Venetian expansion to the Napoli port and imprisoned Venetian traders (Ismail 2001, p.115). Siyasah, policy by the previous rulers has resulted in the desired outcome of losses sustained by Venice in several cities (Mantran \& Bacqué-Grammont, 2003, p. 144). The Accord signed in 1479 AD required Venice to pay a high price to continue its trade activities across the Mediterranea (Inalcik, 1969, p. 22). 
Sultan Muhammad al-Fatih conducted market protection in which he only allowed the imported goods such as iron, rubber, tin, textile, wool, and raw materials required to manufacture its citizens' needs. Another policy by Muhammad al-Faith aimed to protect the market was the increase in tax by $4-5 \%$ to protect Ottoman traders and maintain competition with their Italian counterparts. The result of this policy was the higher profit margin among the local traders boosting the then-deflated economy. The Sultan also banned the export of food across the Black Sea and the Mediterranean Sea. Banned commodities included wheat, vegetable oil, salt, and fish for shipping to Italy to ensure food sustainability of the Ottoman Empire (Inalcik, 1969, p. 135).

Some historians believe that the State's finances at that time were weak because of the rapidly devaluating currency. As a result, Sultan decided to use public-raised funds to cover Jihad's operating costs (Mantran \& Bacqué-Grammont, 2003, p. 144). Historians of the modern age provided an analysis that the living condition of non-muslim minorities were far better than the Muslims in the Ottoman Empire. The Contractual Agreements and Capitulation with Venice and Geneva in 1453 AD impeded economic growth. The activity of trade in the East Sea became sluggish in which income from the tax sector decreased drastically due to the Ottoman Turks relying on the country's tax revenue from European foreign traders (Ismail 2001, p. 73).

Experts and historians like Halil Inalcik analyzed and concluded that the Ottoman Turks' economic progress was due to foreign capitulation given to Venice and Geneva. This was refuted by the policy of Sultan Usmani Muhammad al- 
Fatih which underlined his financial decisions by referring to maqashid shari'ah with siyasah al-maliah. This policy sacrificed political gains for the sake of Muslim people's overall prosperity. It didn't disturb personal interests at all. A second opinion believes that the devaluation of the currency and the decreasing level of manufacturing in Ottoman Turks were caused by Foreign Capitulation and the different views between the successors and members of the Capitulation. They did not have the proper vision and mission. They only had a limited perspective which was the common view and grounds between Orthodox Christianity and Western Catholics after the conquest of Constantinople (Farid Bek AlMuhami, 2009).

During the reign of Sultan Bayazid II (1481-1512), the Hospital of St. John of Jerusalem (the Hospitalers) received the privilege of signing a Foreign Financial Capitulation agreement. At that time, Jerusalem was under the dynasty of the Mamluks who ruled Egypt and Sham. Whereas St. John of Jerusalem settled on the island of Rhodes. The opportunity was given due to the political asylum that they granted to Prince Jem, a political enemy of Sultan Bayazid and a contender for the Ottoman Turks's throne. The Hospitalers blackmailed sultan Bayazid II until the death of Prince Jem at the hands of the French army. During its difficult times, Venice used the opportunity to cease paying custom fees and jizyah resulting in Sultan Bayazid II provided trade facilities to Napoli as retaliation against Venice (Shaw and Shaw 1976, 175). Bologna (Italy) entered into the same agreement in $1490 \mathrm{AD}$, and within the next year, Russia also obtained the same accord, followed by Florence in 1499 AD (Mantran \& Bacqué-Grammont, 2003, p. 192). 
After the political upheavals and instability ended, Sultan Bayazid II reinstated the Foreign Capitulation's consequences against Venice in $1502 \mathrm{AD}$ as was carried out on its predecessors. It was a turning point for the Ottoman's political power in Europe after it reduced the roles of Venice and its sea trade route expansion on the Mediterranean Sea (İnalcık and Quataert 1994, p.76). This policy was carried out after Sultan Bayazid II's forces were victorious against the Venetian fleet that dominated the Mediterranean Sea. The Venetian fleet was defeated by Sultan Bayazid II's fleet despite its novelty and inexperience in the naval war on the open seas after the conquest of Constantinople. Even so, Venice still obtained the privilege of sailing on the Black Sea which had been the Moslem's absolute privilege since the times of Sultan Muhammad II.

During the Sultan Muhammad II's leadership, the capitulation agreement was used to regulate the trading system with foreign countries so that commodities and economic activities would be increased and gold coins could be more circulated which ultimately strengthen the Turkish economy. At this time, the capitulation agreement did not regulate the law and sovereignty of the Ottoman Empire in which the trading system still referred to the Islamic Shari'a very tightly, especially in the Hanafi Mazhab (Hanafi school of thought). Commodity goods that are not permitted by Islamic Sharia are prohibited from being traded, such as liquor and pork. If these goods transited in the Ottoman territory to be brought to Russia and Europe by foreign traders, the Turkish Ottoman would still impose a tax even though they are prohibited commodities as contained in the Hanafi Mazhab. 
In $1512 \mathrm{AD}$, when Sultan Salim ascended the throne from 1470 through 1520, emissaries from various countries came to congratulate him and promised a renewal of agreement made with the previous Sultan (Rari, 2001, p. 75). However, the Sultan rejected the offer and opted to continue the Foreign Capitulation agreements in which such renewal of contract was typical after a change of ruler(Laila, 1977, p. 91). Sultan Salim initiated a new policy as an alternative to the Foreign Capitulation Agreement and imposed a 5\% customs fee on imported goods based on their value. This policy was applied without exception on all merchandise brought by Non-Muslim foreign traders into the Ottoman Turks's territory (Halim, 1987, p. 79).

The next task that the Sultan must prepare was to face the dangers arising from the East of the Islamic region, where a Shiite school of Rebidhah grew and spread and received protection from the Shafawi kingdom. Another task for the Sultan was countering Portuguese trade expansion in the waters of Yemen, Somalia and the Indian Ocean. Portugal grew as a supplier of industrial commodities to Europe with increasing daily demands for handicrafts and spices.

In $1502 \mathrm{AD}$, European ships sailing from Beirut carried only a few commodities such as red peppers and other agricultural produces. At that time, there were not many ships sailed, it was only a few ships were in the port of Alexandria that arrived with great difficulty. This was due to the discovery of a new path in bringing spices and importexport commodities through Cape Hope on the southern tip of the African Continent. They obtained the goods at meager prices and sold them in the Lisbon market. Meanwhile, Venice 
as an old player in the world of commerce experienced difficulties in trading with the Pharaoh of Egypt. They were worried about getting punishment from former communist countries because of their betrayal of trading with Muslim countries. Venice asked the Sultan to lower the price of goods and negotiate with local rulers in India to refrain from selling goods to Portuguese traders.

On the other hand, Venice consulted with the Persian Shah (Shafawi) to re-establish the sea route through the Persian Gulf (Arabian Gulf) toward the middle sea (Ahmad, 1988, p. 75). Sultan Salim, I succeeded in suppressing and isolating Persia from obtaining war equipment, silver, and iron. This resulted in reduced foreign exchange which otherwise would be acquired by the Persian shah.

This Sultan's policy resulted in an adverse effect on the Silk trade that led many silk artisans to abandon their profession and resorted to other trades. Some of them became unemployed and the Silk trade was soon replaced by Armenian craftsmen. The event had threatened the economy of Mecca and Egypt when the Shafawi kingdom held a coalition with Venice to incur harm to the Ottoman Turks.

\section{Trade Conditions and Import Commodities During Capitulation Era}

The significant capitulation period began from the rule of Muhammad al-Fatih after the conquest of Constantinople, Venice, and Geneva in 1454 AH. Since then, the contents of the capitulation agreement were expanded not only to commercial agreements but also to include population and justice. The expansion of the contents of this agreement was 
carried out during the time of Sultan Sulaiman al-Qanuni, on October 2, 1540 (Farid Bek Al-Muhami, 2009). In theory, all important decisions in state policy were related to the fatwa of Shaykh al-Islam, but sometimes the Sultan acted by himself because his decision was considered not to contradict the Shari'ah. But in reality, many decisions were contrary to the Islamic Maqahsid and the benefit of the people (Inalcık \& Quataert, 1994a, p. 235).

Free trade is the first option as a result of Ottoman Turkish policy reaped by the West. This policy imposed restrictions on import tariffs, where tariff provisions could not be changed without obtaining official permission from European parties even though European countries had already secured free-market agreements which led to Foreign Capitulation. The liberal economic policy adopted by Europe and its supporters of Westernization in the 19th century CE demanded the elimination of Tariff Barrier and to expand the trade and economy of the non-European region on a massive scale (Karpat \& Yildirim, 2010, p. 53).

In principle, free trade, which provided a lot of relief and exemption from customs duties for imported goods, must be stopped by the Ottoman Turks. Likewise, with the capitulation agreement provided tax breaks to European countries including France, Venice, Geneva, England, and Italy). The free trade applied the government's policy not to discriminate against imported and exported goods was the market's demand. Free trade applied in the European Union and North America created an open market with trade rules that were strictly determined (İnalcık \& Quataert, 1994a, p. 115). 
The capitulation agreement prevailed in Ottoman Turks freed Western Europeans to settle in Turks with impunity that could not be touched by the Ottoman court. At the beginning of the treaty, the Ottoman Turks and France and related countries had the same legal consequences where they both received impunity. This condition changed after a change in the concept and government system in Western Europe into a unified jurisdiction (Rule of Law), so capitulation law only applied to every citizen of the European Union without exception (Özvar, 2013). Thus the Ottoman Turkish Capitulation agreement with Western Europe was just a trade agreement without any impunity or legal consequences for both citizens who carried out trade activities in the two regions (Turks and Western Europe).

In this case, Western European consulates in Ottoman Turks could protect their citizens freely based on the contents of the capitulation agreement. Criminals committed by Western Europeans could not be tried except by courts in their consulates, because Europe embraced legal unity in a country (Şahin, 2013). The conditions of applying the law in Turks like this were still tolerated by the Hanafi Mazhab, but this was very influential on the stability of the country's economy such as the crime of silver smuggling or silver imports into the Ottoman Turkish region to print excessive currencies that adversely affected the stability commodity prices.

Ibn Khaldun asserted that the country's wealth is not determined by a large amount of money available and circulating in the country, but it is determined by the country's production level and positive balance of payments. A country can print money as much as possible, but if it is not a reflection 
of the rapid growth of the production sector, sufficient cash is no value. The production sector which is the driving force of development absorbs labor, increases the income of workers, and raises the demand for other factors of production. This opinion also shows that international trade became the main topic of the scholars at that time. Countries that export a lot means to have a production capacity more significant than their domestic needs shows that the country is more efficient in its production" (Fitriani, 2019).

Factors of production have experienced a rapid decline due to the tariff barrier being eliminated or minimized. This capitulation agreement also had an impact on production factors, which declined dramatically. Printing of flooding currencies caused massive inflation. The rise of silver smuggling into Turks became an inevitable calamity, caused by the cheap price of silver in Mexico due to the discovery of a new mine by Spain there. The discovery of this new mine also made money printing out of control in the North African region and circulating in Istanbul due to the flood of silver brought by Spain from Mexico. This condition was even more dangerous because of Turks's attachment to Western Europe in the capitulation agreement which made it difficult for Turks to punish the silver smugglers. They generally came from Western Europe (Barkan, 1975).

This method was used to achieve success in building the economy of all member countries of Europe. Tariff barriers applied to agricultural production and other industries followed the division of international cooperation. Before the Free Trade policy was enacted, the European Economic Community could not yet open their respective markets, so 
they searched for other straightforward, open markets, one of which was the Ottoman Empire (İnalcık \& Quataert, 1994b, p. 580).

Sophisticated industrial technical tools had increased the level of manufacturing in European countries, and they required markets to sell those products. At the same time, they were protecting their markets against each other because, in truth, they did not yet believe in the principles of comparative advantage applied by the Free Market. They would only open markets in the East and around the world when they are under pressure, sometimes political and other times military or by force (Rari, 2001, p. 88). The Ottoman Turks accepted this European policy voluntarily in return for support from the European countries to counter the Egyptian crisis and the separatist movement of Muhammad Ali Pasha (1804-1849) (Wallerstein \& Kasaba, 1980, p. 188)

At that time, the reform leaders did not think to protect the industry, especially its domestic production and economy (Wallerstein \& Kasaba, 1980, p. 188). Europeans knew precisely the consequences of the policy that they implemented in other countries in which the industries, production, and economy of these countries would be destroyed although in various seminars, the meetings they made could ensure the privileges and results achieved through global economic cooperation.

To avoid the massive flux of carpet, textiles, and woven fabrics manufactured in Europe at a meager price, the textile and carpet weavers were forced to stop production and look for other jobs. This was due to the absence of tariff protection by the Ottoman Turks, and as a result, the people 
had difficulties in obtaining local woven products including silk and wool, and other fabrics. This condition was caused by a decrease in local production or low prices of imported goods that flooded the Ottoman Empire. Economists in the 1830s predicted the destruction of woven products in the Middle East due to the politics of dumping and the flooding of imported goods (Owen, 1993, p. 101). Indeed, in the 19th century $\mathrm{AD}$, the trading of woven fabrics and cotton fabrics was the world's major trade in which more than half of the British commodities at that time were woven fabric. Within a short period in 1910, the British woven fabrics and cotton fabrics had filled 3/4 of the Ottoman Empire's market (Issawi, 1980, p. 35).

Free market agreements were not limited to maximizing tariffs, but the Ottoman Turks was also prohibited from monopolizing imported goods and stipulating tariffs on exported goods. At the same time, Muhammad Ali Pasha had succeeded in building industry and military in Egypt. Abolition of the government's monopoly rights in local and overseas trade was based on freedom and free trade terms which led to economic destruction and hinders the Government's efforts to conduct a reform. Muhammad Ali Pasya's Industrial and Military development also made the central government lose a huge source of foreign exchange and incurred a very heavy burden for the Ottoman state because Egypt was allowed to carry out transactions and foreign debts that were no longer controlled by the central government. Meanwhile, the repayment of debt made by Egypt was entirely submitted to the Ottoman Turkish government. This was proved very difficult for the central government, especially after the Crimean war in 1854 AD (Pamuk, 1984, p. 20). 
Muhammad Ali tried to ignore the consequences of the free trade agreement, but the foreign hegemony had forced him to overturn all forms of monopoly he undertook and close down all industrial projects that had destroyed smaller enterprises. This foreign intervention abolished the industry in Egypt forever (Karpat \& Yildirim, 2010, p. 119).

Ironically, the European countries used the Egyptian governor against the Sultan, while at the same time incited the Sultan to press his governor. They gave support to Muhammad Ali, the next Governor of Egypt, to break away from the Ottoman Turks while Britain was ready to annex it upon parting with Ottoman Turks (Mikhail, 2011, p. 221). Trade contracts and free-market provided immense space for foreign traders where they were granted facilities and protection to engage in trade activities in the Ottoman Turks. This made the Ottoman Turks' attempt to improve the economy and avoid the adverse impacts of Foreign Capitulation to become increasingly tricky (Encyclopaedia Britannica, Inc, 1987, p. 832).

\section{Reform and Westernization of Economics in the Ottoman Empire}

The improvement and westernization of the economic system that took place in Ottoman Turks showed different results from what expected. Initially, the aim of the change was for the Ottoman Turks to survive in the face of the political and military dangers posed by foreign countries such as Britain, France, Europe, and Russia, who often interfered with Ottoman Turkish domestic affairs. However, after these reforms and westernization were ongoing, causing extraordinary losses and side effects, the reality was far from expectations. Instead of gaining freedom and discretion in 
acting, the Ottoman Turks became increasingly dependent on these countries. The Reformation began with the expansion of foreign capital in the Ottoman Empire and ended in full control of public assets (Owen, 1993, p. 90).

The real reforms were Foreign Capitulation and total surrender to other countries and submission to minority groups living in the country. Uncontrolled railway construction was hazardous to the welfare of local people not to get benefit from the project at all. Capital investment in this railway development project was carried out in a monopoly in which there was no healthy competition that led to progress, and no local and private parties that could contribute to it. This was carried out with an aim at perfecting the western economic structure with interests that were far different from the needs of the people in Ottoman Turks. This reform project destroyed the long-standing structure of Eastern society, while the substitute community structure could not be used for long-term survival (Karpat \& Yildirim, 2010, p. 53).

This condition is similar to what happens in our country today that is with the large influence of foreign economy and capitalist economy binding the country with exponentially rising debts. It is common knowledge that the main purpose of the world's financial institutions established by the developed countries was the provision of debt to countries in economic difficulty. As such, they can eliminate trade barriers in the country and carry out sustainable expansion so that all forms of the national economy can be eliminated. The system makes the Foreign Capital pouring down freely, followed by control of the national economy. This condition will make foreigners in full control of the national assets (Baysis, 2002, p. 196). 
Western democracy does not give any contribution and double standards remain in force. Poverty will still bind the countries to their agreement counterparts. This is the result of the exploitation by Western countries and other advanced countries wherever they operate. The democratic system does not mean anything to the East, merely a tool for Western nations to exploit and fully control their economies (Issawi, 1980, p. 115).

The essence of Democracy is in line with the tactics of the economic Capitalists and Imperialists, but the supporters of the Western countries are developing countries that are unaware that they are merely subordinates, never equals. The supporters of these Western countries are eager to break the traditional shackles and dream of becoming a modern society capable of confronting the progress of the West (Hubazbawem, 1940, p. 239). Westernized statesmen have long been aware of this. Even those who are anti-West feel the need for renewal and improvement given their weak position before the big powers (Wallerstein \& Kasaba, 1980, p. 56). This is very much unlike the politicians of separatist countries who wanted false independence to grow on the ruins of Ottoman Turks. These separatist countries are very weak, they have no ambition at all to escape the restraints of Western countries, although they realized that they would continue to be dictated and would always be at their mercy (Farid Bek Al-Muhami, 2009, p. 221).

The Ottoman Empire made tremendous progress in the 19 th century in which industrial projects employed over half a million workers and civil servants. At that time they were able to properly manage the state's finances, provide health services to the public, establish hundreds of schools, and 
build new farms, rural schools, and hospitals that could serve the community well. Similarly, the construction of bypass roads, telegraph networks, railways, and their maintenance was carried out correctly (Khoury, 1996, p. 496).

Massive modernization has been done in Sultan Abdul Hamid II's era by making Siyasah Syar'iyah, which was a guide to protect the community. He opposed all forms of Westernization, but on the other hand, he faced severe conditions. At that time, the country was preoccupied with refugees from Ottoman-controlled territories overtaken by Russia. An exodus happened that was they filled the city of Istanbul and the remaining Ottoman regions. With minimal finances, depleted natural resources and trained human resources, it was hard to come by. At that time, the Ottoman Turks found it challenging to get an excellent chance to solve domestic problems. The development of the state and the establishment of the army as well as the economy and industry which made the basis of a steady-state take considerable time, while significant enemies such as Russia and Britain would not allow Turks to do such thing. The problems became more complicated since the attacks did not only come from outside alone in which economic difficulties and shortages of highly trained soldiers threatened the stability of the country (McCarthy, 1997, pp. 23-28). At that time, Sultan Abdul Hamid II (1842-1918) was hoping for at least ten years of peace and avoid conspiracy with the West so that he could rebuild his country just like Japan did, away from the European ferocity that concentrated in Southeast Asia and China (Hamid, 1979, p. 97). 
Sultan Abdul Hamid II built Turks by making use of its abundant natural resources. The state's acquisition of Natural Resources was used by Sultan Abdul Hamid II to repay the country's debts that siphoned almost a third of the total assets. The remaining $60 \%$ was used to rebuild the power of its army, and virtually no wealth was left to restore an excellent economic system, as presented by Stanford J.Shaw's statistical data of 1907-1908. Despite the difficult circumstances, the economic development program run by Sultan Abdul Hamid II survived and managed to rebuild the financial system from the devastation caused by the previous leader's capitulations. According to Stanford J.Shaw, Sultan Abdul Hamid II made remarkable economic growth, especially near the end of his rule, which was marked by an increase in the country's revenue by 43\% (Shaw, et. al., 1978, p. 225).

\section{E. The Ottoman Turkish Economic Struggle}

There were many obstacles, hindrances, and traps set by the West so that Turks could no longer rise to rebuild its economic power, but the Ottoman Empire experienced significant development. It could be seen and felt after its collapse. One real barometer that can be used as a reference is when separatist countries in the Middle East could not go back to the starting point when they broke away from their mother, the Ottoman Khilafah. They struggled with their nationalism and eventually surrendered to Western desires, even though they had sufficient Natural Resources to gain independence and advancement of their nation. They remained subservient and obedient to the Western will, condemning themselves to humiliation and away from the hopes of society who struggled with all of the remaining hardships and limitations. 
The Ottoman Empire had at least maintained its political independence and military power. All of these were the essential factors in the economic development which were suppressed continuously by the West both at the beginning of the crisis until the colonial period. At that time, none of the Western countries succeeded in occupying the Ottoman Turks physically, even though they always vied for political and economic gain in exploiting the Ottoman Turks that were in a state of weakness and struggled to survive. The negative impacts caused by the flooding of foreign capital and investment in Ottoman Turks were much smaller than those of the Western nations in the East. Every facility and convenience provided to traders and foreign investors is limited (Pamuk, 2010, pp. 132-142).

It was in contrast to the situation in former colonial countries scattered throughout the world in the 19th century. Ottoman Turks had different attitudes, whether it is about the investors, donor countries and foreign traders who entered their territory. Turks's attitude was also changed to the Governments of major countries. Quataert stated "Ottoman Turkish trade politics is very flexible and elegant only in giving a minimum limit on the targets achieved; this could endanger the European companies because Ottoman Turks still has political freedom (Quataert, 2005, p. 150). He added that the Ottoman Empire had maintained its sovereignty and had also damped the movement of separatist groups to follow Western orders (Quataert, 2005, p. 51). 


\section{F. Economic Stability of the Ottoman Turkish in the 18th \& 19th Centuries AD}

According to the authors' analysis and research results from the scientists like Halil Inalcik, it is the efficiency that led to Ottoman Turks to perform well in the management of public facilities, factories and other facilities related to the welfare of the people (İnalclk \& Quataert, 1994a, p. 195). Ibn Taimiyah also gives the same picture that the stability of a country can be realized through efficiency without significantly reducing the health of the community. Unfortunately, the concept of energy imposed by the Ottoman Turks was hampered by the Foreign Capitulation Agreement that had been active for generations.

For efficiency's sake, the government is allowed to monopolize the factors of production and management of state assets. The Government must control the production of raw materials, water supply company, transportation, electricity, gas, and other minerals for the benefit and stability of the country's economy. If these companies are sporadically managed or handed over to the private sector, it will incur substantial costs that lead to the disruption of public welfare. This concept was undertaken by Turks at the time, in which the economic conditions of the country desperately needed such considerable funds to repay debt and infrastructure development. Western countries highly anticipated the Ottoman period of economic turmoil; actually, they wanted to invest because the abundant natural resources in Turks attracted them. This is different from the conditions of Japan at the time of the restoration era, given its non-strategic location and severe lack of Natural Resources. Advanced and 
Western countries were more interested in China's abundant Natural Resources and its strategic condition.

The government must side with the people rather than participate in complying with the signed capitulation agreement and harming their people. Ottoman Turks has become a big market for Western European products that are undergoing an industrial revolution. Most large countries are protectionists for their trade commodities. Therefore, the choice to bear a momentary disadvantage rather than endless misery is better and that choice does not conflict with the principles of fiqh, especially siyasa shari'iyah. In terms of food, the government must be independent and must be brave to free its nation from import dependence and foreign intervention.

The capitulation agreement is only applied to Western Europe and no longer applied to Eastern European countries. But, this agreement has already become a deadly weapon for the Ottoman government. The terrible inflation that occurred in the Ottoman Empire, continues to increase the number of unemployed and local industries that continue to fall due to the policies of the Ottoman government policies, especially before the time of Sultan Abdul Hamid is no longer in line with siyasah shari'yah al-maliah. The Messenger of Allah (saw) forbade his people to carry out a monopoly and keep him away from Jewish influence in mu'amalah: "From Umar bin Khattab said: The Messenger of Allah has said: "Distributor (expediting distribution), retailers will be given sustenance, while those who carry out hoarding (monopoly) will be cursed." "The Prophet said, I used to forbid you (to save the meat of the victims), because poor people who came from the country of Yemen came to you, so now eat charity, save it (H.R Ibnu Majah)". 
Distribution of food stock must be done immediately if the situation is urgent, so the law of mu'amalah can change according to the benefit faced. The laws that were handed down regarding monopoly, reducing the scales, inhibiting the distribution were mostly done by the Jews and they always damaged the market mechanism. This condition made the Prophet asked his friends to build a separate market from the Jews so that they would soon be free from their influence, which could have the effect of damaging the morals and honor of the Muslims.

After the Prophet migrated to Medina when he saw the chaos of the Madinah community due to the exploitation of the capitalist economic system, the first step taken was to mobilize Abdurrahman bin Auf, a journalist to build an Islamic economic system that was far from Jewish values. Abdurrahman ibn Awf began building a market that was one hundred percent managed by Muslims with a location separate from the Jewish market. The market is named "Suqul Anshar" or the Ansar market.

The Ottoman fiscal and customs policy succeeded in protecting threefold (300\%) compared to the free trade period in 1834 AD. Free Trade was signed at the time of Capitulation, where Turks was in a disadvantaged position and required an agreement with Europe. During this time, Capitulation had become an inconvenience that was successfully canceled in 1914 AD. (Quataert, 2005, p. 156) concluded that: "The Ottoman Empire did not bow to the European Command. Instead, it tried to support and protect its domestic industry"(Khoury, 1996, p. 283). One form of support for domestic trade was to cancel local trade taxes that were also a 
source of income for the much needed in which the Ottoman experienced the crisis in $1874 \mathrm{AD}$ (Issawi, 1980, p. 62). The law was developed to protect local traders and industries and small craftsmen (İnalcık \& Quataert, 1994a, p. 82). The import tariff protection policy was an opportunity for traders who were protected from the hegemony of Great Britain (Khoury, 1996, p. 282). The maneuver by Ottoman Turks to avoid the adverse effects of free trade was a new challenge for Britain that had been running for a quarter of a century in the 19th century (Khoury, 1996, p. 583). Proponents of tariff and customs protection fought against local liberal economic groups and foreign investors from Europe with all of their strength resulting in the victory of local economists who protected themselves from free trade (İnalcık \& Quataert, 1994b, p. 583). This led to the İttihad-ı Osmanî Cemiyeti revolution in $1908 \mathrm{AD}$ which indicated that Westernization did not lead to the desired target because most politicians under the Western influence also rejected Ottoman Turks's full dependency on the West. There were different things in Arab politicians who wanted pseudo-independence and the division of territories became smaller states.

\section{G. Conclusion}

The Capitulation system implanted by the Ottoman Turks brought disaster to the economic and political condition of the country. The Sultan's neglect of the Islamic Shari'ah in conducting Political Contracts and Trade Contracts became a blunder when the empire was unstable. The Political and Economic Crisis backfired, much endangering the Ottoman Empire and Caliphate. Western and foreign nations that 
initially did not gain much from the Political and Economic Contracts gained a powerful position to suppress the weakened Ottoman Turks. Although ultimately Sultan Abdul Hamid II, the people of Ottoman Turks, scholars, entrepreneurs, and economists as well as religious leaders could return the situation and canceled the Contracts that had been ongoing for Hundreds of Years, the conditions of the Ottoman Empire and Caliphate had already changed 180 degrees. The political and economic system based on Islamic Sharia was also destroyed. Foreign Capitulation ended only during the destruction of the Ottoman Caliphate when the Islamic Shari'ah, the ultimate reference in Islamic economic policy in the Ottoman Empire, disappeared alongside the Empire which had been sheltering Muslims for centuries. The West had succeeded in grabbing his nails to destroy the Flat Government with the Shari'a of Islam by doing all sorts of ways although the Ottoman Turks' attempt to escape from Western hegemony remained until the end of his life after the separatist countries tried to break free. This West's success did not only harm Ottoman Turks, but it also led to the total disadvantage of the Islamic world.

The Ottoman Turkish Foreign Capitulation practices under any pretext have provided us with a valuable lesson that free markets are only beneficial to developed countries with active industries. Market protection is significant, as is the prevention of excessive imported commodities to reduce the rate of inflation. The same goes for the prevention of global monopolies that are very detrimental to the State and Society, especially through exerted control over imported goods. 


\section{REFERENCES}

Ahmad, Y. (1988). Daulah Usmaniyah Wa Alaqatuha AlKharijiyah (1st ed.). Yiliz Sarayi Matbaasi.

al-Izari, A.-I. (2003). Usmaniyah Daulah Qi'raah Jadid Li Awamil Inhitat (2nd ed., Vol. 1). Dar al-Arabiyah lil Ulum.

Azawi, R. (2003). Treaty with Britain. Accepting a Protectorate to Keep the Ottoman Turks Out (Vol. 1). Jami'ah Shariah Press.

Barkan, O. L. (1975). The Price Revolution of the Sixteenth Century: A Turning Point in the Economic History of the Near East. International Journal of Middle East Studies, 6(1), 3-28.

Baysis, A. (2002). Bati Medeniyeti Karsisinda Ahmed Midhat Pasya (2nd ed.). Baylan Matbaasi.

Brockelmann, C., Carmichael, J., \& Perlmann, M. (1982). History of Islamic peoples. Routledge \& Kegan Paul.

Encyclopaedia Britannica, Inc (Ed.). (1987). The New Encyclopaedia Britannica (15th ed). Encyclopaedia Britannica.

Farid Bek Al-Muhami, M. (2009). Tarij al-dawla al-'aliyya al'utmaniyya. Dar al-Nafa' is.

Fitriani, R. (2019). Pemikiran Ekonomi Islam Ibnu Khaldun Islamic Economic Thought of Ibnu Khaldun. 2, 15.

Halim, A. (1987). Tarikh Al-Qadha Fi Daulah Usmaniyah (Vol. 1). Dar Al-Kutub Al-Ilmiyah.

Hamid, A. (1979). The rise and fall of the Ottoman Economic (First edition). Anglo Egypt.

Hubazbawem, H. (1940). Tanzimattan Cumhuriyete Kadar Bizde Tarihçilik In Tanzimat: Yüzüncü Yýldönümü Münasebetile. Maarif Matbaasyi. 
Inalcik, H. (1969). The Policy of Mehmed II toward the Greek Population of Istanbul and the Byzantine Buildings of the City. Dumbarton Oaks Papers, 23, 229. https://doi. org/10.2307/1291293.

İnalcık, H., \& Quataert, D. (Eds.). (1994a). An economic and social history of the Ottoman Empire, 1300-1914. Cambridge University Press.

İnalcık, H., \& Quataert, D. (Eds.). (1994b). An economic and social history of the Ottoman Empire, 1300-1914. Cambridge University Press.

Issawi, C. P. (Ed.). (1980). The Economic history of Turks, 18001914. University of Chicago Press.

Karpat, K. H., \& Yildirim, Y. (Eds.). (2010). The Ottoman Mosaic: Exploring models for peace by re-exploring the past (1st ed). Cune Press.

Khoury, D. R. (1996). Halil Inalcik and Donald Quataert, ed., An Economic and Social History of the Ottoman Empire, 1300-1914 (New York: Cambridge University Press, 1994). Pp. 1,057. International Journal of Middle East Studies, 28(2), 289-291. https://doi.org/10.1017/ S0020743800063376.

Kotrani, M. (1986). Daulah Usmaniyah Ru'ayah Jadidah (Vol. 1). Dar an-Nahdhah Misriyah.

Laila, L. S. (1977). Palestine Under Ottoman Periode (Vol. 1). American University Press.

Mantran, R., \& Bacqué-Grammont, J.-L. (Eds.). (2003). Histoire de l'empire Ottoman. Fayard.

McCarthy, J. (1997). The Ottoman Turks: An introductory history to 1923. Longman. 
Meirison, M. (2019). Legal Drafting in the Ottoman Period. Jurnal Ilmiah Al-Syir'ah, 17(1), 39. https://doi. org/10.30984/jis.v17i1.806.

Mikhail, A. (2011). Nature and Empire in Ottoman Egypt: An Environmental History. Cambridge University Press. https://doi.org/10.1017/CB09780511977220.

Owen, R. (1993). The Middle East in the world economy, 18001914 (Rev. pbk. ed). I.B. Tauris.

Özvar, E. (Ed.). (2013). Turk tarihciliginde dört sima: Halil İnalcık, Halil Sahillioğlu, Mehmet Genç, İlber Ortaylı (1. baskı). Timas.

Pamuk, Ş. (1984). The Ottoman Empire in the "Great Depression" of 1873-1896. The Journal of Economic History, 44(1), 107-118. https://doi.org/10.1017/ S0022050700031399.

Pamuk, Ş. (2010). The Ottoman Empire and European capitalism, 1820-1913: Trade, investmentand production (Dig. print. vers. 2010). Cambridge Univ. Press.

Qari, Y. bin A. A. (2001). Daur Imtiyazat al-Ajnabiyah fi Suqud ad-Daulah al-Utsmaniyah. Ummul Quro.

Quataert, D. (2005). The Ottoman Empire, 1700-1922 (2nd ed). Cambrige University Press.

Rari, I. (2001). Imparatorlugun Turkcede (Vol. 1). Alkim Yayinevi.

Şahin, K. (2013). Empire and Power in the Reign of Süleyman: Narrating the Sixteenth-Century Ottoman World. Cambridge University Press.

Salman, S. (2015). Islam Dunyasi Osmanliya Muhtac. Istanbul Matbaasi. 
Shaw, S. J., Shaw, E. K., \& Shaw, S. J. (1978). Reform, revolution, and republic: The Rise of Modern Turks, 1808 - 1975 (1. publ). Cambridge Univ. Press.

Syaqiraat, A. S. (2016). Tarikh al-Idarah al-Utsmaniyah fi Syarq al-Urdun 1864-1918. Darkholid Lilhiyaany wa Tawzii.

Veblen, T. (2005). The theory of the leisure class: An economic study in the evolution of institutions. Elibron Classics, Adamant Media Corp.

Wallerstein, I. M., \& Kasaba, R. (1980). Incorporation Into the World-economy: Change in the Structure of the Ottoman Empire, 1750-1839. Fernand Braudel Center for the Study of Economies, Historical Systems, and Civilizations, State University of New York at Binghamton. https:// books.google.co.id/books?id=TWsEGwAACAAJ. 